\title{
Diet selection by European hares (Lepus europaeus) in the alpine zone of the Snowy Mountains, Australia.
}

\author{
K Green, ${ }^{1}$ N Davis, ${ }^{2}$ WA Robinson, ${ }^{3}$ J McAuliffe ${ }^{4}$ and RB Good ${ }^{4}$ \\ ${ }^{1}$ National Parks and Wildlife Service, Snowy Mountains Region, PO Box 2228, \\ Jindabyne, NSW 2627, Australia \\ kenpetergreen@gmail.com \\ ph +61 (0) 264505538 \\ fax $+61(0) 264505630$ \\ ${ }^{2}$ Department of Zoology, The University of Melbourne, Victoria 3010 \\ ${ }^{3}$ School of Environmental Sciences, Charles Sturt University, Thurgoona, NSW 2641 \\ ${ }^{4}$ Australian National Botanic Gardens, GPO Box 1777, Canberra ACT, 2601
}

\begin{abstract}
European hares (Lepus europaeus) are grazers and open grassland specialists that are replaced in mountain areas of their natural range in the northern hemisphere by browsing/intermediate feeding mountain hares (Lepus timidus) but in their introduced range in the southern hemisphere occupy the alpine zone. We used microhistological identification of plant fragments and germination of seeds in faecal pellets of $L$. europaeus from the Snowy Mountains Australia to determine diet. We asked whether diet shifted and/or diet breadth expanded in response to seasonally reduced food availability, particularly during winter. If so, did the constraints of food availability in the alpine zone lead to the diet mirroring that of $L$. timidus in its native alpine habitat. The diet of $L$. europaeus was dominated by grasses, herbs and shrubs. The main diet items in summer were grasses (70\%) and herbs (28\%). Grasses declined in the diet between summer and autumn when herbs increased to co-dominance, with a further change after establishment of the winter snowpack to a greater preponderance of shrubs (43\% compared with a maximum of 3\% in snow-free months). Lepus europaeus selected a wider range of plants in winter (59 species compared with 39 in summer) and diet was significantly more
\end{abstract}


variable in winter than in autumn or summer (and in autumn than summer). We concluded that the persistence of L. europaeus in alpine areas of the southern hemisphere is testament to their ability to expand their dietary breadth to occupy mountain climatic zones normally occupied by L. timidus.

Keywords dietary breadth, mountain hares, Lepus timidus

\section{Introduction}

The European hare (Lepus europaeus) is native to western, northern, and central Europe and western Asia (Hewson 1977). It has been introduced into a number of countries outside of this range, into Britain possibly > 2000 years ago (Thulin 2003), into Ireland in the mid 1800s (Reid 2011) and Canada in 1912 (Hall and Kelson 1959). In the southern hemisphere it was introduced to New Zealand in 1851 (Wodzicki 1950) and Argentina in 1888 (Grigera and Rapoport 1983). It was introduced successfully into Australia in 1859 (Rolls, 1969) and is now widespread through eastern Australia (Mahood 1983).

Where the distribution of L. europaeus overlaps that of congenerics, it is found at lower altitudes while other hares are found at higher altitudes (Thulin 2003). In mainland Britain, where the mountain hare (Lepus timidus) is native, L. europaeus has generally not extended to the higher mountains, although it will occupy the range of L. timidus when it occurs at low densities (Hewson 1977). Habitat segregation between $L$. europaeus and L. timidus occurs along an altitudinal gradient as a result of competitive exclusion of L. timidus from more productive lowland habitat (Thulin 2003). Continental L. timidus at high altitudes browse predominately on shrubs (Flux and Angermann 1990; Thulin and Flux 2003) but also take a high proportion of grasses (Hulbert et al. 2001), while L. europaeus feed predominately on grasses (Flux and Angermann 1990). It is clear that L. europaeus excludes L. timidus from favoured lowland habitat, however, it is unclear what prevents L. europaeus from invading the higher altitude habitat of $L$. timidus. Throughout the introduced range of L. europaeus in the southern hemisphere there are no other hares and L. europaeus occupies alpine zones as a year-round resident 
up to $2000 \mathrm{~m}$ in New Zealand (Flux 1967), $2150 \mathrm{~m}$ in Australia (K.G. personal observation), $3500 \mathrm{~m}$ in north-central Chile (López-Cortés et al. 2007) and $4000 \mathrm{~m}$ in Argentina (Agustina Barros personal communication 2012).

Sympatric species facilitate co-existence by selecting different resources, an evolutionary outcome of competition (Gause 1934). Niche differentiation, resulting in reduced food niche overlap and thus reduced competition, has been well described among assemblages of co-evolved herbivores (e.g., Bell 1970; Jarman and Sinclair 1979; Bodmer 1991). If the diet of a forager is displaced away from that of its competitor, diet shifts may be observed in response to reduced competition for food resources (Werner 1977; Sih 1993). In particular, short term ecological responses to competitive release may be evident in the form of food niche shifts (Connell 1961), for example, when species are introduced to areas outside their native range where competitors are not present. The current study examined diet selection by L. europaeus up to the altitudinal limit of its Australian distribution where it is released from competition with mammalian herbivores. Our aim was to determine whether year-round occupancy of this climatic zone by L. europaeus is facilitated by diet shifts or expansion of its diet breadth to incorporate food groups at the same rates of use as by L. timidus in its native range, particularly during winter when food availability is further reduced.

\section{Materials and methods}

Study area

The alpine area of the Snowy Mountains consists of $135 \mathrm{~km}^{2}$ above the climatic treeline, including Mt Kosciuszko, the highest mountain in continental Australia at $2228 \mathrm{~m}$ (Green 2009). Lepus europaeus is found throughout this area up to about $2150 \mathrm{~m}$. The major plant communities in the alpine zone are tall alpine herbfield (62\% of the alpine area) and heath (25\%). Tall alpine herbfield is a diverse community with a total of 120 species, dominated by native snow grasses (Poa spp.) and silver snow daisies (Celmisia spp.), 
whereas heath has about 43 species with a variety of species achieving dominance in different heath types (Costin et al. 2000). Snow generally covers this area from June to October with snow depth peaking at regularly monitored sites within the study area at about 125-130 cm, declining to about $20 \mathrm{~cm}$ on higher ridges with exposed sites holding less than $5 \mathrm{~cm}$ (K.G. unpublished data).

Collection of hare faecal pellets

Faecal pellets were cleared from a $1 \mathrm{~m}^{2}$ circle around the base of 50 poles relatively evenly spaced along the Kosciuszko summit track ( $\left.36^{\circ} 27^{\prime} \mathrm{S}, 148^{\circ} 16^{\prime} \mathrm{E}\right)$ and these plots were subsequently used for pellet collection. From the treeline $(1900 \mathrm{~m})$, this track passes through approximately $2.6 \mathrm{~km}$ of heath and then $3.9 \mathrm{~km}$ of tall alpine herbfield to Rawsons Pass (2100 m), close to the upper altitudinal limit of hare distribution, to give a total length of $6.5 \mathrm{~km}$. These two vegetation types were sampled by the 50 plots in approximate proportion (35:65) to their availability (40:60) along the track. To enable seasonal comparisons of diet, fresh hare pellets were collected from plots in April of 2004, 2005 and 2006 for an autumn sample and on 20 January 2006 to constitute a summer sample. Generally the plots could not be used for collection of pellets in winter because of drifting snow obscuring the snow surface along the pole line, so hare pellets were collected opportunistically across the alpine tract through the winters of 2003-2009. Only one winter sample (containing up to five closely associated pellets) was collected on any one day. Pellets of all ages collected from the plots in April 2007 were used for germination trials to identify seeds consumed.

Hare diet analysis

Plants consumed by hares were identified in two ways: by microhistological analysis of fragments in faecal pellets and by identification of seedlings germinated from hare faecal pellets.

Microhistological analysis 
All plant species names follow Costin et al. (2000) to be consistent with vegetation surveys in 2004 and 2011. A reference herbarium of 87 plant species (including 11 weed species) from the alpine zone of the Snowy Mountains was prepared for microhistological analysis following Norbury (1988), with some modifications. To render the epidermis identifiable, dried leaf material was cut into $1 \mathrm{~mm}^{2}$ fragments and digested in $4 \%$ sodium hypochlorite. To stain epidermal fragments, samples were rinsed under running tap water in a $143-\mu \mathrm{m}$ sieve, stood in a $1 \%$ aqueous solution of Gentian Violet for $60 \mathrm{~s}$, rinsed under running tap water, then in $70 \%$ ethanol solution, then under running water again. To mount the plant material a fine brush was used to transfer 1-mL portions to a corn syrup medium on microscopic slides.

Reference plant material was photographed at 10x and 20x, magnification using a Nikon Eclipse 50i microscope mounted with a DC2000M 2 Megapixel Digital Microscope Camera. In addition, untreated reference material was photographed for species with fragile trichomes that were damaged by digestion with sodium hypochlorite. These photographs, coupled with descriptions of diagnostic features (Storr 1961), provided the basis for identifying the plant fragments in pellet samples.

To prepare faecal pellet samples for diet analysis, $10 \mathrm{~mL}$ portions of each sample were digested in $4 \%$ sodium hypochlorite for $3 \mathrm{~h}$. After digestion, a sub-sample from each sample was rinsed, stained and mounted on a microscopic slide, following the procedure used for the reference herbarium.

To determine the proportion of each category of plant epidermal/trichome fragments in faecal pellet samples, point quadrat analysis was used (Norbury 1988), scoring the frequency of fragment types under a cross-hair graticule in one of the ocular lenses of a compound binocular microscope at 100x magnification. Each slide, representing one faecal sample, was moved systematically, half a field of view $(900 \mu \mathrm{m})$ at a time, along longitudinal transects $1 \mathrm{~mm}$ apart. In each field of view, the fragment under the intersection of the cross-hair was identified until 100 fragments per slide had been identified, following Katona and Altbacker (2002). Where possible, fragments were 
identified to family, genus and species. Several plant species in hare pellet samples were identified with a high degree of confidence based on distinct diagnostic features.

However, there was a high degree of overlap among many plant species in epidermal features. In contrast, identification to family level (and in many cases also to genus) was considered accurate, because particular diagnostic features commonly characterise families and/or genera. Presence/absence of fruit/seed/flower material was recorded for each sample based on general diagnostic features for these plant parts.

\section{Germination of seeds from hare faecal pellets}

Germination of seeds was used to confirm species presence in the diet and add new species not detected by microhistological analysis. In total, about 2000 hare droppings were collected, grouped into 50 samples based on the collection plots. The pellets were cold moist stratified over two weeks at $2^{\circ} \mathrm{C}$. Samples were treated in a number of ways to maximize the chances of germination. Sub-samples were incubated in Petrie dishes at three selected temperature combinations: $15 / 5^{\circ} \mathrm{C}, 20 / 10^{\circ} \mathrm{C}, 30 / 20^{\circ} \mathrm{C}$. Lighting was 12 hours on 12 hours off. In addition, from each of the 50 samples, $1 \mathrm{~g}$ of faecal material was spread in a punnet of potting mix and placed in a glasshouse with an under-bench temperature of $22^{\circ} \mathrm{C}$. All pellet samples were left for 100 days and then the germinants counted and identified to genus or species where possible. Duplicate samples were retained in a shade house for a further 140 days in case time was a factor in germination rates.

Food availability

To determine diet selection by $L$. europaeus we used the relationship between diet/season and the general vegetation cover in the Snowy Mountains. For winter, this was based on estimates of herbfield covering about $62 \%$ of the alpine area and heath $25 \%$ and, for the summer and autumn samples, $60 \%$ and $40 \%$, based on the distribution of vegetation along the Kosciuszko Summit Road. Availability of plant species within these vegetation 
types was based on percentage cover in long-term vegetation monitoring plots established in 2004 (Pickering et al. 2008; Pickering and Green 2009).

As the collection of pellets was along a track, there were species in the diet that were peculiar to the trackside (mainly weeds). These species were removed from the diet selection data and the percentage of fragments attributable to native species was recalculated to enable comparisons of diet with the general vegetation cover. It was necessary to aggregate some species (of for example $P o a$ ) into genus to obtain a match between diet and vegetation data, because some fragments in the diet were identified to species but could not be separated in the field, or vice versa.

Statistical analysis

\section{Seasonal variation in diet}

Multivariate analyses were used to compare the assemblages of plant taxa fragments in hare pellets among seasons and years of collection. Firstly, to investigate overall seasonal and annual variations in diet, the average Bray-Curtis similarity (Clarke and Warwick 2001) between samples was compared within and among; seasons; years, and; the year×season interaction using PERMANOVA (Anderson et al. 2001) using 10000 permutations. Significant results were followed up by comparing the 10 different season+site combinations to each other using pairwise PERMANOVA. Some of the pairwise comparisons had too few pellets available to allow sufficient permutations and

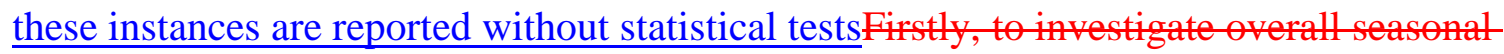
and annual variations in diet, the average Bray Curtis similarity between samples waseompared within and among; seasons; years, and; the yearxseason interaction using PERMANOVA (Anderson et al. 2001) with a minimum of 10000 permutations. Significant results were followed up by comparing the 10 different season+sitecombinations to each other using pairwise PERMANOVA where there were enough pellets available to allow sufficient permutations. Secondly, the pellets were positioned in plant species ordination space using non-metric multidimensional scaling (NMDS) based 
on the Bray-Curtis similarities. Principal axis correlations of the plant species in the ordination space were used to assist in interpretation. All multivariate analyses were performed using Primer-e (Clarke and Gorley 2006). We used Bray Curtis similarity on the range standardised data, specifically to identify plant taxa co-occurring in high relative abundances in the pellets and to give equal weight to all pellets in the analysis. Power transformations (e.g. $\log$, square root or $4^{\text {th }}$ root) on abundances can down weight the contribution of highly abundant taxa in samples when using Bray-Curtis measure (Somerfield 2008), but were not applied for three reasons, 1) the data were standardised counts, hence did not contain extreme abundance values, 2) a transformation would reduce the influence on the similarity from the plant taxa that did occur in high relative abundance in the pellets and give weight to rare taxa (Clarke and Warwick 2001), which was contrary to our aims because we judged that rarer plants were more incidentally consumed and therefore plant species occurring in higher relative frequencies should be recognised as more important in determining diet similarity, and 3) a transformation would tend to increase the similarity values between pellets with higher species richness, also downweighting taxa occurring at higher relative abundances (Austin and Belbin 1982).No transformations were applied to the pellet composition data because the sum of fragments of plant material for each species in each faecal pellet was already rangestandardised to 100.

\section{Diet selection}

A standardised selection index B (Manly 1974; Manly et al. 2002), was used to assess whether faecal pellet content reflected the availability of the common plants in the environment. Confidence intervals for the selectivity index for each species were calculated using 2000 bootstrap samples of the faecal pellet values, which allowed comparisons against the non-preference value for each species.

To reduce the likelihood of spurious results, only plants for which availability in the environment was $2 \%$ or greater were included in analysis of diet selection and values were range standardised to 100 percent. When a faecal pellet contained none of the plant 
taxa used in this analysis $(\mathrm{n}=10)$, the usage value was set to $0.01 \%$ (as per Di Stefano and Newell 2008). The overall availability of plant species was estimated as the weighted availability in the two habitats, where the weight was the length of the sampling transect within each habitat type. As the vegetation availability estimates were made in summer/autumn, and all plants studied are perennial, it was expected that the selection indices in those seasons reflected true selection. In winter the true availability of the same plants is dependent on snow cover, however, the same availability data were used in the selectivity calculations for winter to investigate the direction of non-random feeding.

\section{Comparison with germinants}

Pellets collected for germination trials possibly came from all seasons whereas the summer dietary data came from fresh pellets in January, which is too early for the presence of viable seeds on most plants (Table 1). Hence comparison of plant species occurrence between data from germination trials and from microhistological analysis using simple linear correlation was only made for autumn.

\section{Results}

Microhistological analysis

Both grasses and non-graminoid monocots were recorded in hare faecal pellets, as well as forbs, shrubs, ferns and mosses (Table 1). In total, 70 species of plants were identified in hare faecal pellets (Table 1); Celmisia sp., Dactylis glomerata and Oreomyrrhis sp. in particular were highly represented. Celmisia sp. was ubiquitous, occurring in pellets in all seasons, averaging $8 \%$ of plant material in pellets in summer, $14 \%$ in autumn and $20 \%$ in winter (Table 1). In summer, 39 species were identified in faecal pellets with 46 identified in autumn and 59 in winter. Grasses were the main diet item of L. europaeus in summer $(70 \%)$ with herbs $(28 \%)$ being the other dominant group. However, the representation of grasses in the diet declined between summer and autumn when herbs rose to co-dominance (both about 48\%) (Table 2). Shrubs were dominant in the diet in 
winter (43\% compared with a maximum of 3\% in snow-free months) while the frequency of grasses and herbs both fell below $30 \%$ (Table 2).

Germination of seeds from hare faecal pellets

In total, 64 species were represented in the 564 germinants (Table 1). The dominant germinants were Poa spp. (54\%) and Chionochloa frigida was the most widespread species across all samples (73\% of samples). Non-native species made up $10.6 \%$ of germinants. Although there was good agreement between presence/absence of species identified using germinants and microhistological analysis, some were detected with germination only and some detected with microhistological analysis only. However, there was little correlation between the number of germinants and the distribution of plants in the diet from microhistological analysis in autumn (Table 1). Taking just the 13 species that contributed $>1 \%$ of germinants and together making up $84.2 \%$ of germinants, the correlation with distribution of plants in the diet from microhistological analysis in autumn was low $(\mathrm{r}=0.0792)$.

Seasonal diet

There was a significant difference in plant species composition in pellets among seasons (Pseudo $\mathrm{F}=12.4, \mathrm{df}=2,101, \mathrm{p}<0.0001$, Unique permutations $=9900)$ and among years (Pseudo $\mathrm{F}=2.2, \mathrm{df}=5,101, \mathrm{p}<0.0001, \mathrm{UP}=9866)$. However the difference among years was dependent on season (Pseudo $F=2.1, \mathrm{df}=2,101, \mathrm{p}<0.005$, UP $=$ 9899)." There was a significant difference in plant species compesition in pellets among seasons (Pseudo $\mathrm{F}=12.4, \mathrm{df}=2,101, \mathrm{p}<0.0001$ ) and among years (Pseudo $\mathrm{F}=2.2, \mathrm{df}=$ $5,101, p<0.0001)$. However the difference among years was dependent on season(Pseudo $F=2.1, d f=2,101, p<0.005$ ). The follow up analysis comparing all 10 levels of year and season against each other showed that pellet samples collected in autumn were generally similar among years and although 2005 and 2006 were found to be statistically different, they still had $32 \%$ similarity (Table 3). Winter samples among years were generally more similar than to other season samples, but the power of the 
permutation tests comparing winter years was restricted by the smaller samples sizes. Nevertheless, winter samples from every year were always significantly different to every summer and autumn sample (Table 3).

The ordination of pellet samples revealed clear differences in diet composition between winter and other seasons (Fig. 1). Whilst there was some overlap between the composition of autumn and summer pellets, the ordination confirmed a general difference in diet between those seasons. Variability in diet composition between autumn and winter among years is evident in the ordination (Fig. 1). Principal ordination axis correlations confirmed Celmisia sp., Grevillea australis, and Richea continentis as important contributors to the difference between pellet composition in winter compared to other seasons. Dactylis glomerata was associated with summer diets whilst Oreomyrrhis sp. was associated with autumn diets (Fig. 1).

\section{Diet selection}

Celmisia sp. appeared significantly more often in hare pellets than expected based on availability in the habitat in all three seasons, while Kunzea muelleri and Empodisma minus were significantly under-represented in pellets in all three seasons (Fig. 2). The shrub Grevillea australis was selected against in summer and autumn but appeared more regularly in pellets in winter (Fig. 2). The other shrub only taken in winter but in smaller amounts was Baeckea. The grasses Trisetum spicatum and Poa spp. were selected for in summer and occurred in pellets in proportion to availability in autumn. Craspedia spp., Phebalium ovatifolum and Epacris spp. were almost absent in pellets collected in summer but appeared in proportion to availability in autumn pellets (Fig. 2).

A number of species appeared among the germinants but were not detected during diet analysis. Two of these species came from monospecific genera within the mountains and were not represented in the reference herbarium so could not be detected during diet analysis and the others were likely misidentified due to nondescript epidermal features. 


\section{Discussion}

Diet overview

The diet of L. europaeus in the alpine zone of the Snowy Mountains was dominated by grasses, herbs and shrubs; rushes sedges and ferns were not consumed in large quantities at any time. The diet of L. europaeus in alpine Australia has similarities with that in alpine New Zealand, reflecting floristic-affinities between the two floras (Costin et al. 2000). In two alpine studies in New Zealand, the main plant genera taken by $L$. europaeus were Chionochloa, Celmisia and Poa (Flux 1967; Horne 1979). Celmisia sp. constituted $11 \%$ and $24 \%$ of the diet of hares in the two studies and $8-20 \%$ seasonally in the Snowy Mountains. It is possibly preferred for its palatability or because it lacks herbivore defences. Oreomyrrhis was unimportant in the diet of hares in New Zealand whereas Chionochloa, important in both studies in New Zealand (Flux 1967; Horne 1979) only averaged $2.5 \%$ of the diet in the Snowy Mountains, but after Poa spp. did constitute the next highest proportion of germinants (Table 1). Aciphylla are grazed by $L$. europaeus in New Zealand (Wong and Hickling 1999) but were uncommon in the diet in the Snowy Mountains. Acaena was important (5.3\%) in the diet of L. europaeus in alpine north-central Chile (López-Cortés et al. 2007), although it was avoided in the Snowy Mountains. It appears that L. europaeus has adapted differently to a novel southern hemisphere flora in different regions but it is hard to interpret the importance of the differences without information on vegetation availability at the sites studied.

If seeds were harvested incidentally whilst grazing, and germination was not retarded or advantaged by the digestive process, then some correlation between species detected using microhistological and germination methods would be expected. This was not the case - some species were detected using the germination method only, or in different proportions using the two methods. For example, Chionochloa was uncommonly detected using microhistological techniques but among the top three species recorded germinating. As such, it appears that hares are harvesting seed heads preferentially, probably for nutritional reasons. Higher consumption of reproductive plant parts may be a 
compensation for the reduced food value of vegetative parts (Paupério and Alves 2008). If seed heads are selected because they are highly palatable, material may not appear in faecal pellets because it is digested; additionally, because seed head epidermal features are similar to grass leaf features there may have been seed head material present that was classified as leaf. In either case the amount that germinates under-represents consumption and the true importance of seed would be better studied using stomach contents.

Germination trials should, therefore, be seen not only as a complementary technique to maximise detection (and improve the accuracy of identification) of species in the diet, but also as a means of identifying key components of the diet that are likely to be underrepresented in traditional diet analysis techniques.

\section{Diet selection}

European hares are selective feeders, with $93 \%$ of plants in arable land in Austria consumed less than would be expected based on availability (Reichlin et al. 2006). The current study suggests that the forb Celmisia is the preferred food of L. europaeus in the Snowy Mountains, while the widespread Baeckea, Kunzea and Empodisma were generally avoided and the strongly aromatic Prostanthera and Podocarpus were avoided completely, as also observed for Podocarpus in New Zealand (Flux 1967). The grasses Trisetum spicatum and Poa spp. were preferred in summer and autumn as would be expected for a grazer. In Chile, L. europaeus were also shown to feed preferentially on grasses in summer, taking Deschampsia, Deyeuxia and Hordeum at levels higher than expected by chance (López-Cortés et al. 2007). However, Chionochloa is common at the sites where hare faecal pellets were collected in the Snowy Mountains, but rare in pellets and, in contrast to New Zealand, other evidence of grazing such as hedging of Chionochloa was not recorded.

Seasonal variations in diet

Grasses were the main diet item of L. europaeus in summer but their importance declined in autumn when herbs rose to co-dominance in the diet, possibly due to differentially 
changing nutrient status of the two groups, particularly a reduction in palatability of grasses post-seeding. Poaceae inflorescences were common in summer faecal samples, occurring in two-thirds of samples but became less common in autumn faecal pellets, falling to only a quarter of the summer level. At this time seed, predominantly of Poa spp., became more common in pellets, increasing by about 50\%. Craspedia spp., Phebalium ovatifolum and Epacris spp. were almost absent from the diet in summer but appeared in proportion to availability in autumn. It appears that summer produces an abundance of food in which preferences may be exercised. In contrast, in autumn as preferred foods decline in palatability post-seeding, L. europaeus no longer selectively consume them, instead reverting to consumption of foods in proportion to their availability. In winter, hares are even less able to exercise dietary choice and the food eaten is that which projects above the snow or occurs in areas of snow denudation. The main change in L. europaeus diet in winter was the greater preponderance of shrubs (43\% compared with a maximum of $3 \%$ in snow-free months) with Grevillea, a genus almost unused in summer and autumn, becoming important. At the same time, the frequency of grasses and herbs both fell below $30 \%$ although hares were still able to find Celmisia on windswept areas such as passes and glacial hummocks, as also observed in New Zealand (Flux 1967).

The expansion in hare diet breadth to include shrubs or trees when the ground is snow covered and ground vegetation unavailable has previously been found for L. europaeus in lowland Germany following severe winter conditions (Rödel et al. 2004) and in New Zealand after a $3 \mathrm{~m}$ snowfall (Flux 1967). Lepus timidus also feeds more commonly on shrubs in winter, with heather (Calluna vulgaris) making up 20-50\% of the diet in AprilOctober but increasing to 50-90\% in winter (Hulbert et al. 2001; Hewson 1977) when old heather (not a preferred food) may be the only vegetation protruding through the snow (Hewson 1989). When snow is deep, L. timidus also feed on taller shrubs such as gorse (Ulex europaeus) or bark and twigs of trees (Hewson 1977). L. timidus will also graze Erica spp. when food availability is low (Hewson 1989) and in this study, although intake levels were low, Epacris spp. (Ericaceae) increased in the diet of L. europaeus from summer through autumn to winter. Lepus americanus also shifts its diet to non-preferred 
woody vegetation when the ground is snow covered and preferred food items are not available (Telfer 1972; Pease et al. 1979). Hence, increased dietary breadth by hares in winter is neither unique to L. europaeus nor to Australia, but browsing on shrubs by $L$. europaeus does not approach the degree achieved by L. timidus.

\section{Competition}

If, as suggested by a number of studies (Wolfe et al. 1996; Thulin 2003) L. europaeus excludes $L$. timidus from mutually favoured habitat in their native range, what prevents $L$. europaeus invading the higher altitude habitat of L. timidus? In several mountain locations with native Leporidae, introduced L. europaeus have not thrived, for example Scotland or north-east America (Hewson 1976; Thulin 2003). In contrast, in the absence of L. timidus in Australia, New Zealand and South America L. europaeus can occupy alpine areas and appears to be able to expand its diet breadth to cope with poor or scarce food. However, shrubs seem to be a less important food source in alpine New Zealand than in alpine Australia, with only Aristotelia fruticosa attracting attention from hares in New Zealand in winter in an area where the large tussocks of Chionochloa also projected above the snow (Flux 1967; Horne 1979). Similarly, L. europaeus has demonstrated a relatively broad diet niche in alpine north-central Chile where food was scarce but shrubs were not consumed in large quantities (López-Cortés et al. 2007).

Lepus europaeus, in the Snowy Mountains therefore, are well adapted to life as an alpine animal with hares, un-noticed at alpine altitudes in the early1970s, increasing to population densities similar to those in upland areas of Britain in a little over 30 years (Green and Pickering in press). Its ability to broaden its diet niche to incorporate shrubs such as Grevillea that are not eaten in summer is likely key to its survival in this environment during periods of food shortage. However, it does not solely rely on shrubs, hence its success may also relate to the winter availability of a preferred food (i.e. the herb Celmisia).

No-where in its southern hemisphere alpine distribution does L. europaeus facecompetition from native herbivores of similar size and it is unclear what would happen if 
such a competitor was present. It is possible that $L$. europaeus would be outcompeted or possibly the presence of the preferred dietary item Celmisia (in New Zealand andAustralia) would mean diet segregation could occur even in the alpine zone.

\section{References}

Anderson MJ (2001) A new method for non-parametric multivariate analysis of variance. Aust Ecol $26: 32-46$

$\underline{\text { Austin MP, Belbin L (1982) A new approach to the species classification problem in floristic }}$ analysis. Aust J Ecol 7:

Bell RHV (1970) The use of the herb layer by grazing ungulates in the Serengeti. In Warson A (ed) Animal populations in relation to their food resources. Blackwell Scientific Publications, Aberdeen, pp 111-123

Bodmer RE (1991) Influence of digestive morphology on resource partitioning in Amazonian ungulates. Oecologia 85:361-365.

Clarke KR, Gorley RN (2006) PRIMER v6: User Manual/Tutorial. PRIMER-E, Plymouth

Clarke KR, Warwick RM (2001) Change in marine communities: an approach to statistical analysis and interpretation, 2nd edition. PRIMER-E, Plymouth.

Connell J (1961) The influence of interspecific competition and other factors on the distribution of the barnacle Chthamalus stellatus. Ecology 42:710-743

Costin AB, Gray M, Totterdell CJ, Wimbush DJ (2000) Kosciuszko Alpine Flora, 2nd edn. CSIRO, Melbourne

Di Stefano J, Newell G (2008) Diet selection by the swamp wallaby (Wallabia bicolor): feeding strategies under conditions of changed food availability. J Mammal. 89:1540-1549

Flux JEC (1967) Hare numbers and diet in an alpine basin in New Zealand. Proc N Z Ecol Soc 14:1526

Flux JEC and Angermann R (1990) The hares and jackrabbits. In Chapman JA, Flux JEC eds Rabbits, hares and pikas: Status survey and conservation action plan. IUCN/SSC Lagomorph Specialist Group, Oxford

Gause GF (1934) The struggle for existence. Williams and Wilkins, Baltimore 
Green K (2009) Causes of stability in the alpine treeline in the Snowy Mountains of Australia - a natural experiment. Aus J Bot 57:171-179

Green K, Pickering CM (in press) Limited effect of hare grazing and short term climatic variations on the most common alpine vegetation community in the Snowy Mountains, Australia. Plant Ecol Divers

Grigera D, Rapoport EH (1983) Status and distribution of the European hare in South America. J Mamm 64:163-164

Hall E, Kelson K (1959) Mammals of North America. The Ronald Press Co, New York

Hewson R (1976) A population study of mountain hares. (Lepus timidus) in north- east Scotland from 1956-1969. J Anim Ecol 45:395-414

Hewson R (1977) Order Lagomorpha Genus Lepus. In Corbet GB, Southern HN eds The handbook of British mammals. Blackwood, Oxford, pp 140-150

Hewson R (1989) Grazing preferences of mountain hares on heather moorland and hill pastures. J Appl Ecol 26:1-11

Horne RSC (1979) Seasonal and altitudinal variations in diet and abundance of the European hare (Lepus europaeus Pallas) in Tongariro National Park, New Zealand. M.Sc. thesis Massey University, Palmeston North

Hulbert IAR, Iason GR, Mayes R (2001) The flexibility of an intermediate feeder: dietary selection by mountain hares measured using faecal n-alkanes. Oecologia 129:197-205

Jarman PJ, Sinclair ARE (1979) Feeding strategy and the pattern of resource partitioning in ungulates. In Sinclair ARE, Norton-Griffiths N eds Serengeti: Dynamics of an Ecosystem. University of Chicago Press, Chicago, pp 130-163

Katona K, Altbäcker V (2002) Diet estimation by faeces analysis: sampling optimisation for the. European hare. Folia Zool 51:11-15

López-Cortés F, Cortés A, Miranda E, Rau JR (2007) Dietas de Abrothrix andinus, Phyllotis xanthopygus (Rodentia) y Lepus europaeus (Lagomorpha) en un ambiente altoandino de Chile. Revista Chilena de Historia Natural 80:3-12

Mahood IT (1983) Brown hare. In Strahan R (ed) Complete Book of Australian Mammals. Angus and Robertson, Sydney, p 480

Manly BFJ (1974) A model for certain types of selection experiment. Biometrics 30:282-94 
Manly BFJ, McDonald LL, Thomas DL, McDonald TL, Erickson WE (2002) Resource Selection by Animals: Sample Design and Analysis for Field Studies, 2nd edn. Kluwer, Dordrecht

Norbury GL (1988) Microscopic analysis of herbivore diets - a problem and a solution. Aust Wildl Res 15:51-57

Paupério J, Alves PC (2008) Diet of the Iberian hare (Lepus granatensis) in a mountain ecosystem. Eur J Wildl Res 54:571-579

Pease J L, Vowles RH, Keith LB (1979) Interaction of snowshoe hares and woody vegetation. J Wildl Manage 43:43-60

Pickering C, Green K (2009) Vascular plant distribution in relation to topography, soils and microclimate at five GLORIA sites in the Snowy Mountains, Australia. Aust J Bot 57:189-199

Pickering C, Hill W, Green K (2008) Vascular plant diversity and climate change in the alpine zone of the Snowy Mountains, Australia. Biodiversity Conserv 17:1627-1644

Reichlin T, Klansek E, Hackländer K (2006) Diet selection by hares (Lepus europaeus) in arable land and its implications for habitat management. Eur J Wildl Res 52:109-118

Reid N (2011) European hare (Lepus europaeus) invasion ecology: implication for the conservation of the endemic Irish hare (Lepus timidus hibernicus). Biol Invasions 13:559-569

Rödel HG, Völkl W, Kilias H (2004) Winter browsing of brown hares: evidence for diet breadth expansion. Mamm Biol 69:410-419

Rolls EC (1969) They all ran wild. Angus and Robertson, Sydney

Sih A (1993) Effects of ecological interactions on forager diets: competition, predation risk, parasitism and prey behaviour. In Hughes RN (ed) Diet selection: An interdisciplinary approach to foraging behaviour. Blackwell Scientific Publications, Oxford, pp 182-211

Somerfield PJ (2008) Identification of the Bray-Curtis similarity index: Comment on Yoshioka (2008). Mar Ecol Prog Ser 372:303-306

Storr GM (1961) Microscopic analysis of faeces, a technique for ascertaining the diet of herbivorous mammals. Australian Journal of Biological Sciences 14:157-165.

Telfer ES (1972) Browse selection by deer and hares. J Wildl Manage 36:1344-1349

Thulin CG (2003) The distribution of mountain hares Lepus timidus in Europe: A challenge from brown hares L. europaeus? Mamm Rev 33:29-42

Thulin CG, Flux JEC (2003) Lepus timidus (Linnaeus 1758). Schneehase. In Krapp F (ed) Handbuch der Saugetiere Europas, Band 3/II, Lagomorpha. Aula Verlag, Koblenz, pp 155-185 
Werner EE (1977) Species packing and niche complementarity in three sunfishes. Amer Nat 111:553-578

Wolfe A, Whelan J, Hayden TJ (1996) The diet of the mountain hare (Lepus timidus hibernicus) on coastal grassland. J Zool Soc Lond 240:804-810

Wodzicki KA (1950) Introduced mammals of New Zealand. N.Z. Department of Science and Industry, Research Bulletin 98:1-255

Wong V, Hickling GJ (1999) Assessment and management of hare impact on high altitude vegetation. Sci For Conserv 116:1-40

Table 2 Seasonal differences in percentage occurrence of life forms estimated in the diet of European Hares based on microhistological analysis of faecal pellets.

Life form Summer Autumn Winter

\begin{tabular}{crrr}
\hline Moss & 0.0 & 0.13 & 0.2 \\
Fern & 0.0 & 0.0 & 0.2 \\
Rush & 0.1 & 0.1 & 0.8 \\
Sedge & 0.4 & 0.5 & 0.3 \\
Grass & 69.9 & 47.3 & 28.0 \\
Herb & 28.3 & 48.8 & 27.6 \\
Shrub & 1.4 & 3.3 & 43.1 \\
\hline
\end{tabular}

Table 3. Average Bray-Curtis Similarity between hare diet composition within (diagonal) and among season+years, estimated from hare faecal pellets using microhistological analysis. Comparisons in bold are significantly different $(\mathrm{p}<0.01)$.

\begin{tabular}{|c|c|c|c|c|c|c|c|c|c|}
\hline Season & & & Autumn & Summer & & & & & \\
\hline & Year & 04 & 05 & 06 & 03 & 05 & 06 & 07 & 09 \\
\hline \multirow{2}{*}{ Autumn } & 2004 & 31 & & & & & & & \\
\hline & 2005 & 31 & 35 & & & & & & \\
\hline
\end{tabular}




\begin{tabular}{|c|c|c|c|c|c|c|c|c|c|c|c|}
\hline & 2006 & 33 & 32 & 37 & & & & & & & \\
\hline Summer & 2006 & 28 & 39 & 29 & 53 & & & & & & \\
\hline \multirow{6}{*}{ Winter } & 2003 & 14 & 11 & 14 & 9 & 28 & & & & & \\
\hline & 2004 & 14 & 11 & 12 & 9 & 33 & 32 & & & & \\
\hline & 2005 & 13 & 11 & 11 & 11 & 22 & 27 & 23 & & & \\
\hline & 2006 & 6 & 6 & 5 & 8 & 11 & 18 & 17 & 21 & & \\
\hline & 2007 & 17 & 13 & 12 & 11 & 18 & 16 & 15 & 6 & 21 & \\
\hline & 2009 & 16 & 10 & 13 & 9 & 33 & 31 & 26 & 16 & 17 & 29 \\
\hline
\end{tabular}

\section{Figure Captions}

Fig. 1 European Hare diet composition in non-metric multi-dimensional scaling ordination space based on Bray-Curtis dissimilarity of plant species composition estimated using microhistological diet analysis based on faecal pellets (Stress $=0.21$ ). Vectors show direction of Spearman's correlation of plant species with the ordination axes. Only taxa with correlation coefficients greater than 0.5 are shown and the circle defines the maximum correlation of 1.0.

Fig. 2 Selectivity of common plant species in the diet of European hares, based on microhistological analysis of faecal pellets. The bars represent Manley's selectivity index, the range bars show the $95 \%$ confidence interval and the dashed vertical line shows the expected index for no preference. 
Winter Summer

- 2003 ○ 2006

- 2004 Autumn

- $2005 \diamond 2004$

- $2006 \square 2005$

จ $2007 \triangle 2006$

$+2009$

$\underset{\text { elmisla }}{+} \diamond$

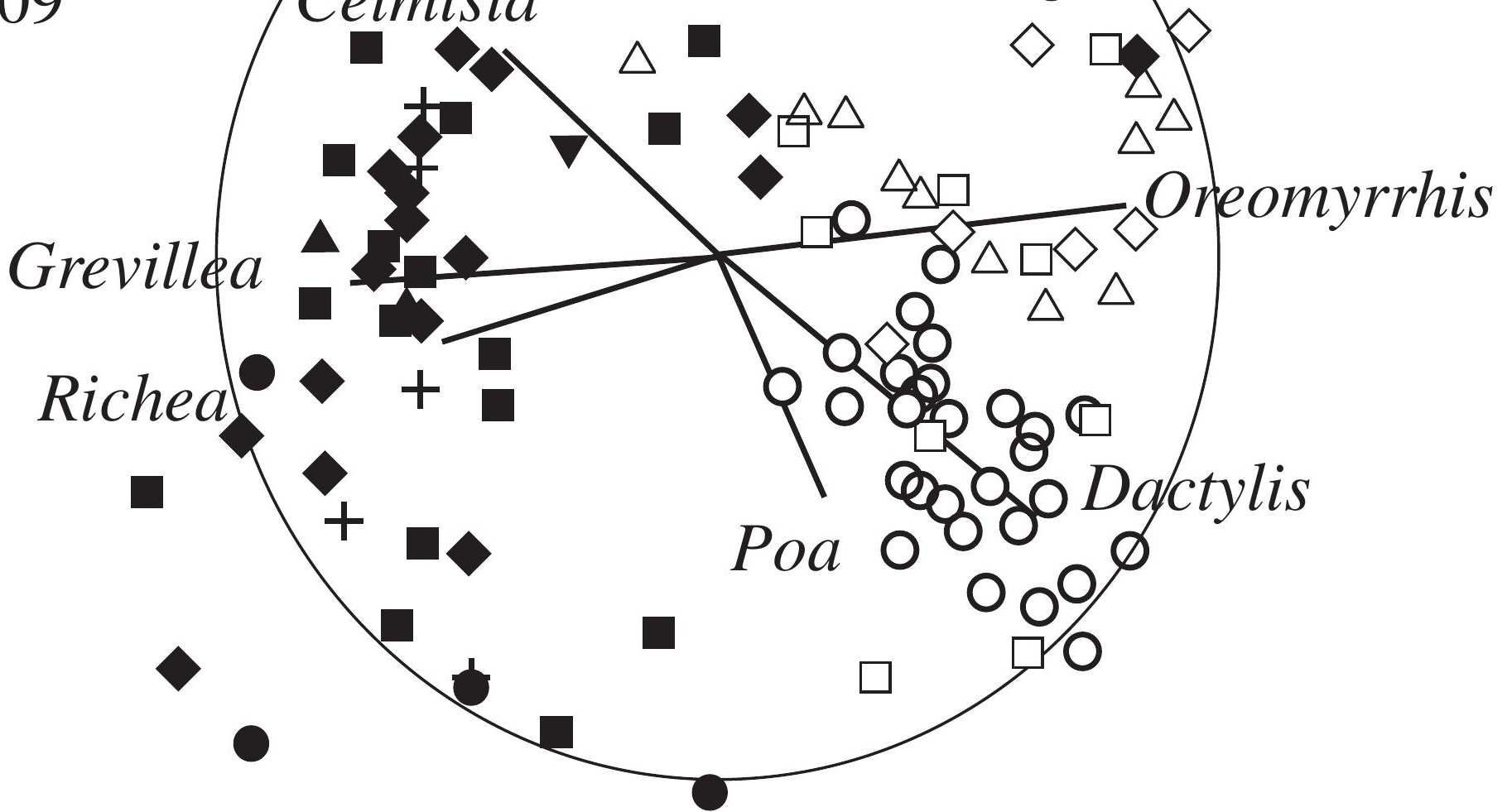




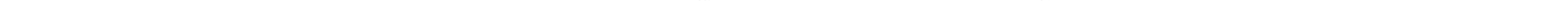


Table 1 Plants species represented in hare faecal pellets. Because only 76 plant species were in the reference herbarium representing the 212 species in the alpine zone some were only identified to genus. Two species of Brachyscome, Carex, Deyeuxia and Epacris and three species of Ranunculus were identified from microhistological analysis. All germinants except Stylidium sp. were identified to species except where that species has not yet been described (e.g.Acaena sp.). Where there are data for individual species of germinants within a genus the percentage of germinants is given in plain lettering with their combined data as a genus given in bold. All names follow Costin et al. (2000) except Austrodanthonia alpicola that has since been included in Rytidosperma and is included with that genus group here. Oreomyrrhis spp. and Phebalium ovatifolium have since changed to Chaerophyllum spp. and Nematolepis ovatifolia.

\begin{tabular}{|c|c|c|c|c|c|c|}
\hline \multirow[t]{2}{*}{ Species } & \multirow{2}{*}{$\begin{array}{l}\text { Life- } \\
\text { form } \\
{ }^{*} \text { weed }\end{array}$} & \multicolumn{3}{|c|}{ Occurrence $(\%)$ in diet in: } & \multirow{2}{*}{$\begin{array}{l}\text { Proportion } \\
(\%) \text { of } \\
\text { germinants }\end{array}$} & \multirow[t]{2}{*}{$\begin{array}{l}\text { Seeding } \\
\text { day of year }\end{array}$} \\
\hline & & Summer & Autumn & Winter & & \\
\hline Lycopodium fastigiatum & Moss & 0.00 & 0.13 & 0.06 & 0.0 & \\
\hline Polystichum proliferum & Fern & 0.00 & 0.00 & 0.16 & 0.0 & \\
\hline Empodisma minus & Rush & 0.10 & 0.10 & 0.80 & 0.0 & \\
\hline Luzula sp. & Rush & 0.00 & 0.00 & 0.02 & 0.2 & \\
\hline Luzula alpestris & Rush & & & & 0.2 & 30_97 \\
\hline Carex spp. & Sedge & 0.34 & 0.36 & 0.28 & 0.5 & \\
\hline Carex gaudichaudiana & Sedge & & & & 0.5 & 21_80 \\
\hline Carpha sp. & Sedge & 0.03 & 0.00 & 0.00 & 0.0 & \\
\hline Oreobolus sp. & Sedge & 0.00 & 0.13 & 0.06 & 0.0 & \\
\hline Agrostis sp. & Grass & 3.40 & 3.67 & 2.84 & 1.6 & \\
\hline Agrostis meionectes & Grass & & & & 0.7 & 31 \\
\hline Agrostis muelleriana & Grass & & & & 0.9 & \\
\hline Chinochloa frigida & Grass & 0.37 & 1.87 & 3.92 & 19.5 & 35_100 \\
\hline Dactylis glomerata & Grass* & 43.50 & 13.10 & 1.04 & 2.2 & \\
\hline Deschanpsia caespitosa & Grass & 0.30 & 0.00 & 0.00 & 0.0 & \\
\hline Deyeuxia spp. & Grass & 3.26 & 3.93 & 2.25 & 0.0 & \\
\hline Festuca rubra & Grass* & 1.07 & 2.57 & 9.84 & 1.4 & \\
\hline Phleum pratense & Grass* & 2.37 & 7.40 & 1.27 & 0.9 & \\
\hline Poа аппиа & Grass* & 0.70 & 0.13 & 0.67 & 1.8 & \\
\hline Poa costiniana & Grass & 8.47 & 3.87 & 3.94 & 19.3 & 65_79 \\
\hline Poa fawcettiae & Grass & 1.53 & 2.60 & 0.27 & 20.2 & 46 \\
\hline Poa hiemata & Grass & 0.00 & 2.27 & 1.16 & 11.2 & \\
\hline Poa pratensis & Grass* & 0.97 & 0.40 & 0.02 & 1.1 & \\
\hline Poa saxicola & Grass & 0.00 & 0.60 & 0.00 & 0.0 & \\
\hline Rytidosperma sp. & Grass & 1.63 & 1.20 & 0.65 & 1.0 & \\
\hline Rytidosperma & & & & & & \\
\hline (Austrodanthonia) alpicola & Grass & & & & 0.2 & $31-93$ \\
\hline Rytidosperma australe & Grass & & & & 0.2 & 61_88 \\
\hline Rytidosperma nivicola & Grass & & & & 0.2 & 30_74 \\
\hline Rytidosperma pumilum & Grass & & & & 0.4 & 73 \\
\hline Trisetum spicatum & Grass & 2.33 & 3.73 & 0.04 & 0.2 & 71_93 \\
\hline Acetosella vulgaris & Herb* & 0.00 & 0.00 & 0.10 & 0.5 & \\
\hline Achillea millefolium & Herb* & 0.07 & 0.00 & 0.04 & 0.4 & \\
\hline
\end{tabular}




\begin{tabular}{|c|c|c|c|c|c|c|}
\hline Aciphylla sp. & Herb & 0.00 & 0.80 & 0.76 & 0.0 & \\
\hline Asperula sp. & Herb & 0.23 & 0.67 & 0.86 & 0.2 & \\
\hline Asperula pusilla & Herb & & & & 0.2 & \\
\hline Australopyrum velutinum & Herb & 0.10 & 0.00 & 0.37 & 0.4 & 22_98 \\
\hline Brachyscome sp. & Herb & 2.53 & 2.67 & 0.53 & 1.3 & \\
\hline Brachyscome scapigera & Herb & & & & 0.7 & 35_78 \\
\hline Brachyscome stolonifera & Herb & & & & 0.4 & 36_98 \\
\hline $\begin{array}{l}\text { Brachyscome sp. (aff. } \\
\text { tadgellii) }\end{array}$ & Herb & & & & 0.2 & \\
\hline Celmisia sp. & Herb & 8.40 & 13.93 & 20.25 & 2.3 & \\
\hline Celmisia costiniana & Herb & & & & 1.4 & 23_73, \\
\hline Celmisia pugioniformis & Herb & & & & 0.9 & 51_98 \\
\hline Chionogentias muelleriana & Herb & 0.00 & 0.00 & 0.00 & 0.5 & 52_97 \\
\hline Craspedia spp. & Herb & 0.03 & 0.57 & 0.27 & 2.4 & \\
\hline Craspedia alba & Herb & & & & 0.2 & 44_66 \\
\hline Craspedia costiniana & Herb & & & & 0.4 & $52 \_66$ \\
\hline Craspedia jamesii & Herb & & & & 1.1 & 32 \\
\hline Craspedia leucantha & Herb & & & & 0.5 & 57_93 \\
\hline Craspedia maxgrayi & Herb & & & & 0.2 & $23 \_44$ \\
\hline Dianella tasmanica & Herb & 0.00 & 0.00 & 0.78 & 0.2 & \\
\hline Diplaspis nivis & Herb & 0.07 & 0.20 & 0.02 & 0.0 & \\
\hline Epilobium sp. & Herb & 0.10 & 0.00 & 0.10 & 0.2 & \\
\hline Epilobium gunnianum & Herb & & & & 0.2 & \\
\hline Erigeron sp. & Herb & 0.00 & 0.00 & 0.06 & 0.2 & \\
\hline Erigeron setosus & Herb & & & & 0.2 & \\
\hline Euchiton sp. & Herb & 0.00 & 0.00 & 1.02 & 0.2 & \\
\hline Euchiton argentifolius & Herb & & & & 0.2 & 80_89 \\
\hline Euphrasia collina & Herb & 0.00 & 0.17 & 0.00 & 0.4 & 24_98 \\
\hline Geranium sp. & Herb & 0.00 & 0.00 & 0.00 & 0.4 & \\
\hline Geranium antrorsum & Herb & & & & 0.4 & \\
\hline Helichrysum scorpioides & Herb & 0.00 & 0.00 & 0.00 & 0.4 & \\
\hline Hypochaeris radicata & Herb* & 0.00 & 0.10 & 0.04 & 0.5 & \\
\hline Leucochrysum albicans & Herb & 0.03 & 0.00 & 0.00 & 0.0 & \\
\hline Microseris lanceolata & Herb & 1.57 & 1.37 & 0.00 & 0.5 & 75 \\
\hline Neopaxia australasica & Herb & 0.00 & 0.00 & 0.00 & 0.5 & 23_92 \\
\hline Oreomyrrhis sp. & Herb & 14.80 & 26.93 & 1.71 & 1.0 & \\
\hline Oreomyrrhis brevipes & Herb & & & & 0.2 & $73 \_89$ \\
\hline Oreomyrrhis ciliata & Herb & & & & 0.2 & $27 \_72$ \\
\hline Oreomyrrhis eriopoda & Herb & & & & 0.4 & $33 \_89$ \\
\hline Oreomyrrhis pulvinifica & Herb & & & & 0.2 & $23 \_35$ \\
\hline Pentachondra pumila & Herb & 0.00 & 0.00 & 0.02 & 0.7 & $23 \_86$ \\
\hline Plantago glacialis & Herb & 0.00 & 0.00 & 0.00 & 0.4 & 75_98 \\
\hline Plantago muelleri & Herb & 0.00 & 0.00 & 0.00 & 0.2 & $23 \_74$ \\
\hline Podolepis robusta & Herb & 0.00 & 0.00 & 0.00 & 0.4 & 67_99 \\
\hline Prasophyllum sp. & Herb & 0.00 & 0.03 & 0.00 & 0.0 & \\
\hline Ranunculus spp. & Herb & 0.13 & 0.00 & 0.39 & 1.3 & \\
\hline Ranunculus dissectifolius & Herb & & & & 0.4 & 27_83 \\
\hline
\end{tabular}




\begin{tabular}{|c|c|c|c|c|c|c|}
\hline Ranunculus graniticola & Herb & & & & 0.5 & 6_94 \\
\hline Ranunculus niphophilus & Herb & & & & 0.4 & 44_98 \\
\hline Scleranthus sp. & Herb & 0.00 & 0.00 & 0.12 & 0.2 & \\
\hline Scleranthus biflorus & Herb & & & & 0.2 & 64_79 \\
\hline Senecio sp. & Herb & 0.13 & 0.97 & 0.00 & 0.4 & \\
\hline Senecio pectinatus & Herb & & & & 0.2 & 98 \\
\hline Senecio pinnatifolius & Herb & & & & 0.2 & 24_97 \\
\hline Stackhousia pulvinarus & Herb & 0.00 & 0.00 & 0.00 & 0.2 & 53_98 \\
\hline Stellaria pungens & Herb & 0.03 & 0.00 & 0.02 & & \\
\hline Stylidium sp. & Herb & 0.03 & 0.13 & 0.00 & 0.4 & 61 \\
\hline Taraxacum officinale & Herb* & 0.00 & 0.00 & 0.00 & 0.4 & \\
\hline Trifolium repens & Herb* & 0.00 & 0.00 & 0.02 & 1.4 & \\
\hline Viola betonicifolia & Herb & 0.00 & 0.00 & 0.00 & 0.2 & 98 \\
\hline Wallenbergia ceracea & Herb & 0.00 & 0.13 & 0.06 & 0.2 & 34_90 \\
\hline Acaena sp. & Shrub & 0.00 & 0.00 & 0.02 & 0.5 & \\
\hline Baeckea sp. & Shrub & 0.00 & 0.00 & 0.04 & 0.0 & \\
\hline Ewartia nubigena & Shrub & 0.23 & 0.00 & 0.14 & 0.0 & \\
\hline Epacris spp. & Shrub & 0.03 & 1.27 & 1.54 & 0.0 & \\
\hline Grevillea australis & Shrub & 0.00 & 0.00 & 15.96 & 0.0 & \\
\hline Hovea montana & Shrub & 0.00 & 0.57 & 4.37 & 0.0 & \\
\hline Kunzea muelleri & Shrub & 0.00 & 0.03 & 0.00 & 0.0 & \\
\hline Leucopogon montanus & Shrub & 0.20 & 0.47 & 2.78 & 0.0 & \\
\hline Melicytus sp. & Shrub & 0.30 & 0.10 & 0.33 & 0.0 & \\
\hline Olearia sp. & Shrub & 0.00 & 0.50 & 3.25 & 0.0 & \\
\hline Oxylobium ellipticum & Shrub & 0.00 & 0.10 & 1.61 & 0.0 & \\
\hline Ozothamnus sp. & Shrub & 0.57 & 0.07 & 2.63 & 0.0 & \\
\hline Phebalium ovatifolium & Shrub & 0.00 & 0.03 & 1.53 & 0.0 & \\
\hline Podolobium alpestre & Shrub & 0.00 & 0.00 & 0.25 & 0.0 & \\
\hline Richea continentus & Shrub & 0.03 & 0.13 & 8.65 & 0.0 & \\
\hline
\end{tabular}




\section{University Library}

\section{- M M N E R VA A gateway to Melbourne's research publications}

Minerva Access is the Institutional Repository of The University of Melbourne

Author/s:

Green, K;Davis, NE;Robinson, WA;McAuliffe, J;Good, RB

Title:

Diet selection by European hares (Lepus europaeus) in the alpine zone of the Snowy Mountains, Australia

\section{Date:}

2013-10-01

\section{Citation:}

Green, K., Davis, N. E., Robinson, W. A., McAuliffe, J. \& Good, R. B. (2013). Diet selection by European hares (Lepus europaeus) in the alpine zone of the Snowy Mountains, Australia. EUROPEAN JOURNAL OF WILDLIFE RESEARCH, 59 (5), pp.693-703. https:// doi.org/10.1007/s10344-013-0723-x.

Persistent Link:

http://hdl.handle.net/11343/283150 